\title{
UVODNIK
}

\section{KONCEPT KREPITVE ODPORNOSTI DRUŽBE}

Pojem koncept krepitve odpornosti družbe se najpogosteje uporablja v različnih dokumentih Evropske unije. Med najpomembnejše spada Globalna strategija Evropske unije za zunanjo in varnostno politiko iz leta 2016. Pojem odpornosti največkrat povezujemo z zdravjem in odpornostjo organizma na različne viruse, bakterije in druge pojave, ki ogrožajo posameznikovo zdravje. Odpornost družbe pa zveni kot skupek dejavnosti, ki je potreben zato, da bi bila celotna družba odporna na tisto, kar nas vse skupaj ogroža. Najpogosteje to imenujemo grožnje, in takrat, ko se pojavi pojem groženj, se nemudoma znajdemo na področju varnosti. Vendar koncept krepitve odpornosti družbe zajema veliko več kot samo zoperstavljanje varnostnim grožnjam. Strategija EU za varno unijo se sklicuje na definicijo, ki jo je uporabil Svet EU o odpornosti že leta 2013, in sicer, da je odpornost družbe »zmožnost posameznika, gospodinjstva, skupnosti, države ali regije, da se pripravi na stresne razmere in pretrese, se jim zoperstavi, se jim prilagodi in si od njih hitro opomore, ne da bi to ogrozilo dolgoročne razvojne možnosti«.

Dokumenti, ki so nastali v Evropski uniji na temo koncepta krepitve odpornosti družbe, so seveda zelo pomembni. Dolgo časa v razvoju Evropske unije pojem varnosti ni bil med prioritetami. S pojavom različnih neprijetnosti in nevarnosti, ki jih povzročajo podnebne spremembe, terorizem, množične in ilegalne migracije, družbene in politične spremembe, potrjujejo, da je koncept krepitve odpornosti družbe še kako pomemben, in to v najširšem mogočem smislu.

Odpornost slovenske družbe je bila že velikokrat na preizkušnji. Naj samo na kratko omenimo prelomno leto 1991, ko se je za vse prebivalke in prebivalce Slovenije veliko spremenilo. Sledila so leta, ko so poplave pokazale vso svojo moč in razsežnost. Žled leta 2014 nas je posebej presenetil in zahteval nov, drugačen razmislek o zagotavljanju nacionalne varnosti. Sledile so množične migracije leta 2015, ki so se kot evropska migrantska kriza končale marca 2016. Ilegalne migracije 
leta 2020 zahtevajo intenzivno delovanje Policije in Slovenske vojske. Covid-19 je presenetil ves svet na različnih področjih in bo pustil svoj pečat tudi v prihodnje. Med epidemijo so bili v dejavnosti za preprečitev, zajezitev in pomoč pri organizaciji vključeni številni državni organi, tudi Slovenska vojska.

Vse naštete izkušnje so samo razlog več za pripravo koncepta krepitve slovenske odpornosti družbe, ki bo kot sestavni del evropske družine narodov lahko prispeval več k varnosti in blaginji v domovini in širše, v Evropi.

Tokratna številka je nastala v okviru koncepta krepitve odpornosti družbe. To je zelo široko področje, zato smo se osredotočili samo na nekaj tem, ki so povezane z varnostjo, obrambo in oboroženimi silami.

Kitajska, varnostni izziv za Evropsko unijo je prispevek Mojce Pešec. Vpliv Kitajske je v svetu vedno večji, največji pa je na ekonomskem in geopolitičnem področju. Ta država je vedno bolj prisotna tudi na drugih področjih. Avtorica se v prispevku najbolj posveča političnim, varnostnim in vojaškim vidikom vplivanja Kitajske na Evropsko unijo, ki posledično vplivajo tudi na Slovenijo.

Pojem kibernetskega prostora je gotovo področje, ki se med vsemi najhitreje razvija in tako omogoča neslutene priložnosti za vse, ki želijo kaj spremeniti na bolje, pa tudi za tiste, ki želijo povzročiti škodo ali se kako drugače okoristiti. Hitremu napredku je težko slediti. Pogoj za strokovne in znanstvene razprave je poenotenje terminologije, o čemer piše Damjan Štrucl v prispevku z naslovom Terminološka zmeda pri zagotavljanju varnosti v kibernetskem prostoru.

Kako kritična je nacionalna kritična infrastruktura in kako to ugotavljati, je težava, ki je k pisanju spodbudila Darka Lubija. Kaj vse vpliva na določitev kritičnosti in v kakšnih okoliščinah so določene kritične infrastrukture bolj kritične od drugih. Metodološki model za ugotavljanje nacionalne kritične infrastrukture lahko pomembno prispeva k obravnavi te problematike, a varnostne okoliščine se nenehno spreminjajo.

Slovenska vojska sodeluje s Policijo pri zagotavljanju učinkovitega varovanja schengenskih meja od 2015. Obe organizaciji imata vsaka svoje zakonsko določene naloge. Sta različni, kar izhaja iz njunega različnega poslanstva. O tem, kaj njuno sodelovanje v resnici pomeni s pravnega in organizacijskega vidika, piše Gregor Potočnik v prispevku Sodelovanje Slovenske vojske in Policije pri nalogah notranje stabilnosti in varnosti Republike Slovenije.

Specialne sile so elitne enote v oboroženih silah, ki izvajajo posebno zahtevne naloge. Pripadniki takih sil morajo dosegati višje standarde fizične in psihične pripravljenosti v primerjavi s pripadniki drugih vojaških enot. Višje standarde navadno dosegajo moški, kar je vzrok, da so ženske pripadnice specialnih sil bolj izjema kot pravilo. 
Kakšna je potem Perspektiva žensk v specialnih silah, se sprašujeta Karmen Poklukar in Pavel Vuk.

Avtorji prispevkov v Sodobnih vojaških izzivih imajo različno znanje in izkušnje. Varnostni konflikti v različnih oblikah pustijo posledice. Ena takih so tudi mine, ki so ostale na Kosovu po tistem, ko je večina odšla. Nekaj tistih, ki so ostali, se vsak dan srečuje z nevarnostjo ubojnih sredstev. Svoje izkušnje pri razminiranju Kosova z bralci deli Matjaž Bizjak v prispevku Minska nevarnost na Kosovu v obdobju od 1999 do 2001.

Drugo leto bomo praznovali tudi 30-letnico slovenske samostojnosti v eni od številk Sodobnih vojaških izzivov. Bralke in bralce vabimo k pisanju prispevkov na temo varnosti, obrambe in vojaštva s poudarkom na prihodnosti. 